\title{
Quality characteristics of frozen cookie dough using rice flour of super yield Korean rice varieties
}

\author{
Nayoung Lee ${ }^{*}$, Ki-Young $\mathrm{Ha}^{2}$ \\ ${ }^{1}$ Department of Food Science and Biotechnology, Kunsan National University, Gunsan 573-701, Korea \\ ${ }^{2}$ National Institute of Crop Science, Rural Development Administration, Iksan 570-080, Korea
}

\section{초다수성 쌀가루를 이용한 쿠키용 냉동반죽의 품질 특성}

\author{
이나영 ${ }^{*} \cdot$ 하기용 ${ }^{2}$ \\ ${ }^{1}$ 군산대학교 식품생명공학과, ${ }^{2}$ 농촌진흥청 국립식량과학원
}

\begin{abstract}
The highly producible rice cultivars, hanareum and dasan 2 , were prepared and investigated for their physicochemical properties, and the quality characteristics of frozen cookie dough with rice flour according to the thawing time were measured. The water, ash, crude protein, amylose, and damaged starch contents of rice flour, as well as its water holding capacity, particle size, and Hunter color value, were measured. The water, ash, and crude protein contents of the hanareum and dasan 2 rice flours were shown to range from 7.28 to $13.14 \%$, from 0.35 to 0.39 , and from 6.05 and $8.68 \%$, respectively. The protein content of the control group was higher than that of hanareum and dasan 2 rice flours. The amylose contents of the hanareum and dasan 2 rice flour were 19.05 and $23.04 \%$, respectively. The damaged starch content and water holding capacity of the control group were lower than those of the hanareum and dasan 2 rice flours. The particle sizes of the samples were 48.54 50.05 $\mathrm{\mu m}$. The lightness values of the hanareum, and dasan 2 rice flour, and of the control were 93.72, 93.51 and 92.63, respectively. The quality characteristics of the gluten-free frozen cookie dough were investigated. The lightness of the cookie made with frozen cookie dough decreased according to the by thawing time, but the diameter of the cookie did not differ significantly. The hardness of the cookie made with rice frozen dasan 2 rice dough was lower than that of the cookie made with frozen hanareum rice dough.
\end{abstract}

Key words : rice flours, high producible rice cultivar, rice starch, rice frozen dough, rice cookie

\section{서 론}

냉동반죽(frozen dough)은 제빵 공정 중에 반죽을 동결시 킴으로써 발효를 억제하여 냉동 저장하고 이를 필요에 따라 해동 후 남은 공정을 진행하여 완제품을 생산하는 것을 말한다(1,2). 냉동반죽의 장점은 소비자에게 신선한 제품을 공급하고, 생산계획 원활화, 다품종 소량생산체제 개선, 노

*Corresponding author. E-mail : nylee@kunsan.ac.kr Phone : 82-63-469-1826, Fax: 82-63-469-7448

Received 4 September 2014; Revised 23 October 2014; Accepted 21 November 2014.

Copyright (c) The Korean Society of Food Preservation. All rights reserved.
동력 절감, 반품 감소, 베이커리 설비와 장소를 경감시킬 수 있는 등의 장점이 있다 $(3,4)$. 이러한 냉동반죽은 냉동제 법에 따라 성형냉동, 생지 냉동, 반제품 냉동(par-baked freezing), 발효 후 냉동, 발효 중 냉동, 완제품 냉동이 있다 (5). 그러나 동결에 의한 효모의 발효 지연, 해동 후 구웠을 때 부피 감소, 효모 사멸 등과 같은 품질의 저하를 초래한다 (4). 이러한 단점을 보완하기 위하여 글루텐 손상을 방지하 기 위해 산화제 첨가, 부피 개선을 위해 sodium stearoyl lactylatem(SSL), diacetyl tartaric acid esters of monoglycerides (DATEM), ethoxylated monoglyceride(EOM)와 같은 유화제 첨가 및 xanthan gum, guar gum, carboxy methyl cellulose 등과 같은 hydrocolloid를 첨가하여 얼음 결정 형태 감소 및 냉동과 해동 안전성 부여와 같은 연구 결과들이 보고되 


\section{고 있다(6-9).}

또한, 냉동반죽을 이용한 빵의 품질은 반죽 제제 뿐만 아니라 반죽 혼합 시간, 동결 속도, 저장 기간, 해동 속도와 같은 변수에 의해 영향을 받으며(10-15), 이러한 요인들은 $\mathrm{CO}_{2}$ 생산을 감소시키는 효모 활성의 감소, 글루텐 네트워 크 손상과 같은 작용이 협력적 혹은 독립적으로 작용한다고 보고하였다(16). 국내 냉동생지에 관한 연구로는 냉동조건 탐색(17), 검류 첨가(9,18), 유화제 첨가(19), 밀가루의 회분 함량 및 단백질 함량에 의한 제품 품질 영향(20,21), 활성글 루텐을 이용한 발효연구 등(1)을 통한 최종 제품의 물성 및 품질에 관한 연구가 보고 되었으며, 주로 밀가루를 이용 한 연구로 쌀가루를 이용한 냉동 반죽의 연구는 매우 제한 적이다

우리나라의 가공용 벼 품종 육성은 1990 년대 중반 이후 밥쌀용 품종 뿐만이 아니라 유색미, 향미와 더불어 물성 개선, 영양성 및 수량성 증대와 같은 다양한 가공용 및 기능 성 쌀 품종이 개발되고 있다(22). 최근 국내 쌀 생산량은 꾸준히 증가하는데 반해 소비량의 감소로 쌀의 소비를 촉진 하기 위한 쌀가공 제품의 개발이 요구되고 있다(23). 국내 쌀 소비는 주로 주식인 밥과 가공용으로 떡류, 한과, 주류 등에 이용되고 있다(24). 그러나 최근 쌀가공산업은 즉석밥 류 및 죽류 산업이 점차 확대되어 가고 있고, 더불어 쌀과자 류, 음료 및 조미식품류, 쌀가루, 빵류, 선식류 등으로 다양 화되고 밀가루 소비에 대한 대체성이 점차 확대되어 가고 있다(25). 초다수성 쌀품종개발 연구는 $1,000 \mathrm{~kg} / 10 \mathrm{a}$ 를 목 표로 미질보다 수량성 향상에 초점을 맞추어 개발하고 있 고, 통일형 초다수성 품종은 쌀국수, 쌀빵, 막걸리 등 가공용 으로 활용시 원가 절감에 유리하다(26). 본 연구에서는 쌀의 소비증진을 위하여 가공용 초다수성 국내 쌀품종 쌀가루의 이화학적 특성에 대해 알아보고 이를 이용하여 제조한 쿠키 용 쌀냉동반죽의 품질 특성에 대해 조사하였다.

\section{재료 및 방법}

\section{실험재료}

본 연구에 사용된 국내 초다수성 쌀품종인 한아름 및 다산 2호 시료는 국립식량과학원에서 제공받아 사용하였 다. 제공받은 쌀 품종은 건식기류 분쇄기(ACM 250, Hankok Crusher Co., Inchon, Korea)를 이용하여 분쇄하였다. 분쇄 된 시료는 냉장보관하면서 실험에 사용하였고, 대조구로 사용된 시료는 박력밀가루로 시중에서 구입하여 사용하였 다.

\section{일반성분 분석 및 아밀로오즈 함량}

쌀가루의 수분함량, 회분 및 단백질 함량은 각각 $\mathrm{AOAC}$ 방법(27)에 준하여 3회 반복하여 분석하였다. 아밀로오즈
함량은 Juliano(28)의 방법에 의해 측정하였다. 아밀로오즈 함량은 쌀가루 $100 \mathrm{mg}$ 에 $95 \%$ ethanol $1 \mathrm{~mL}$ 과 $\mathrm{NaOH} 9$ $\mathrm{mL}$ 을 첨가하여 분산시키고 $100^{\circ} \mathrm{C}$ water bath에 넣어 10 분 동안 반응시켰다. 반응 후 반응용액 $5 \mathrm{~mL}$ 을 취하고 $1 \mathrm{~N}$ $\mathrm{CH}_{3} \mathrm{COOH} 1 \mathrm{~mL}$ 과 $\mathrm{I}_{2}-\mathrm{KI}$ 용액 $2 \mathrm{~mL}$ 을 첨가한 후 증류수를 이용하여 $100 \mathrm{~mL}$ 이 되도록 정용하였으며, 30 분 동안 방치 한 후 분광광도계를 이용하여 $620 \mathrm{~nm}$ 에서 흡광도를 측정하 였다.

\section{손상전분, 입도분석 및 색도 분석}

손상전분 함량은 Gibson 등(29)의 방법에 준하여 enzymatic assay kits(MegaZyme Pty., Ltd., Wicklow, Ireland) 를 사용하여 측정하였다. 쌀가루의 입자 크기는 Multi-wavelength lazer particle size analyzer(LS 13320, Beckman Coulter, Inc., CA, USA)를 이용하여 측정하였고, 색도분석은 색차계(Color JS55, Color Technology System Co., Tokyo, Japan)를 이용하여 측정하였으며 색도는 $\mathrm{L}^{*}$, $a^{*}, b^{*}$ 값으로 나타내었다.

\section{수분 결합 능력}

쌀가루의 수분 결합 능력은 Medcalf DF and Gilles $\mathrm{KA}(30)$ 및 $\mathrm{Kim}$ 등(31)의 방법에 준하여 측정하였다. 쌀가루 $1 \mathrm{~g}$ 에 증류수 $40 \mathrm{~mL}$ 을 가하여 교반기를 사용하여 실온에서 1 시간 동안 교반한 후 $2,000 \times \mathrm{g}$ 에서 30 분간 원심분리한 후 분리된 상징액을 제거하여 침전된 무게를 측정하였다. 수 분 결합 능력은 다음 식에 의해 계산하였다.

\section{수분결합능력 $(\%)=($ 침전된 시료의 무게 $(\mathrm{g})$-처음 시료의 무게 $(\mathrm{g})) /$ 처음 시료의 무게 $(\mathrm{g}) \times 100$}

\section{쿠키용 쌀냉동반죽 제조 및 품질 분석}

쿠키용 쌀냉동반죽을 제조하기 위하여 쌀가루, 마가린, 설탕, 계란, 우유 등의 재료를 믹서기를 이용하여 혼합한 후 반죽을 만들고, 제조된 반죽은 밀대를 이용하여 밀어준 뒤 커팅기를 이용하여 모양을 성형하였다. 쿠키용 냉동반 죽의 성형은 높이 및 직경이 $5 \times 50 \mathrm{~mm}$ 가 되도록 모양을 성형하였으며, 성형된 반죽은 $-20^{\circ} \mathrm{C}$ 냉동고에서 24 시간 냉동하였다. 냉동된 쿠키용 쌀냉동생지는 실온에서 해동시 간에 따라 해동하여 $180^{\circ} \mathrm{C}$ 오븐에서 20 분 정도 구운 후 상온에서 30 분 동안 방랭 과정을 거쳐 쿠키의 높이 및 직경 을 측정하였다. 또한 쿠키의 경도는 texture analyser(TA-XT, Stablemicro systems Ltd, Surrey, UK)를 이용하여 쿠키 두께 의 $10 \%$ strain, $3.0 \mathrm{~mm} / \mathrm{sec}$ 조건으로 분석하였다. 모든 시료 는 3 회 반복하여 분석하였다.

\section{통계처리}

통계처리는 SAS(statistical analysis system) 통계 
package(7.0, SAS Institute, Cary, NC, USA)를 이용하여 평 균 및 표준편차에 대한 분산분석(ANOVA)에 의해 유의성 을 검정하였고, Duncans의 다중범위 검정(Duncan's multiful range test)을 실시하여 유의적인 차이를 $\mathrm{p}<0.05$ 수준에서 검정을 하였다.

\section{결과 및 고찰}

일반성분 분석, 아밀로오즈 함량, 손상전분 및 수분 결합 능력

초다수성 쌀품종인 한아름 및 다산 2호를 국립식량과학 원에서 제공받아 건식 기류 분쇄기로 분쇄하여 본 연구에 사용하였고 대조구로는 시중에 판매하는 박력 밀가루를 사용하였다. 초다수성 쌀가루의 수분 함량, 회분 함량 및 단백질 함량의 결과는 Table 1 과 같다. 한아름, 다산 2 호 쌀가루, 대조구의 수분 함량 및 회분 함량은 각각 $7.70,7.28$, $13.14 \%$ 및 $0.39,0.35,0.39 \%$ 로 나타났다. 또한 단백질 함량 은 대조구가 $8.68 \%$ 로 나타나 한아름 및 다산 2호 쌀가루의 6.62 및 6.05\%보다 높게 나타났다. 초다수성 쌀가루의 아밀 로오즈 함량, 손상전분 및 수분 결합 능력을 분석하였다 (Table 2). 한아름 및 다산 2호 쌀가루의 아밀로오즈 함량은 각각 19.05 및 $23.04 \%$ 를 나타냈다. 손상전분의 경우 한아름 및 다산 2호 쌀가루의 손상전분 함량은 각각 13.73 및 $14.09 \%$ 의 전분 손상도를 나타냈으며, 대조구의 경우 $4.45 \%$ 의 전분 손상도를 나타내어 대조구에 비해 쌀가루의 전분 손상도가 높음을 확인하였다. 수분 결합력의 경우 대조구 의 경우 $177.69 \%$ 의 수분 결합력을 보인 반면 한아름 및 다산 2호 쌀가루의 수분결합력은 270.50 및 $281.17 \%$ 로 높

Table 1. General components of the super-yield Korean rice varieties

\begin{tabular}{cccc}
\hline Samples & $\begin{array}{c}\text { Water contents } \\
(\%)\end{array}$ & $\begin{array}{c}\text { Ash contents } \\
(\%)\end{array}$ & $\begin{array}{c}\text { Crude protein } \\
(\%)\end{array}$ \\
\hline Control & $13.14 \pm 0.28^{\mathrm{a} 1)}$ & $0.39 \pm 0.01^{\mathrm{a}}$ & $8.68 \pm 0.08^{\mathrm{a}}$ \\
Hanareum & $7.70 \pm 0.16^{\mathrm{b}}$ & $0.39 \pm 0.01^{\mathrm{a}}$ & $6.62 \pm 0.08^{\mathrm{b}}$ \\
Dasan 2 & $7.28 \pm 0.49^{\mathrm{b}}$ & $0.35 \pm 0.01^{\mathrm{b}}$ & $6.05 \pm 0.08^{\mathrm{c}}$ \\
\hline
\end{tabular}

${ }^{1)}$ Different letters within the same column differ significantly $(\mathrm{p}<0.05)$.

Table 2. Amylose and damaged starch contents and water holding capacities of the super-yield Korean rice varieties

\begin{tabular}{cccc}
\hline Samples & $\begin{array}{c}\text { Amylose contents } \\
(\%)\end{array}$ & $\begin{array}{c}\text { Damaged starch } \\
(\%)\end{array}$ & $\begin{array}{c}\text { Water holding } \\
\text { capacity }(\%)\end{array}$ \\
\hline Control & $26.61 \pm 1.96^{\mathrm{al})}$ & $4.45 \pm 0.03^{\mathrm{c}}$ & $177.69 \pm 0.89^{\mathrm{c}}$ \\
Hanareum & $19.05 \pm 0.78^{\mathrm{c}}$ & $13.73 \pm 0.06^{\mathrm{b}}$ & $270.50 \pm 5.75^{\mathrm{b}}$ \\
Dasan 2 & $23.04 \pm 0.52^{\mathrm{b}}$ & $14.09 \pm 0.04^{\mathrm{a}}$ & $281.17 \pm 5.70^{\mathrm{a}}$ \\
\hline
\end{tabular}

${ }^{1)}$ Different letters within the same column differ significantly $(\mathrm{p}<0.05)$.
은 수분 결합력을 나타내는 것으로 확인하였다. Lee(32)는 시중 유통되는 쌀가루의 수분 함량, 수분 결합 능력을 분석 한 결과 각각 7.64 14.97\% 및 95.22 232.94\%로 나타났고, 아밀로오즈 함량은 4.32 22.45\% 범위를 나타낸다고 보고 하였다. Lee와 Lee(33)는 건식, 습식 및 반습식 제분방법에 의한 쌀가루의 수분함량은 9.52 11.89\%를 나타낸다고 보 고하였으며 쌀가루의 수분흡수지수(WAI)의 경우 습식제 분한 쌀가루의 지수가 높았다고 보고하였다. Jun 등(34)은 전분 손상도는 제분 횟수가 많아짐에 따라 건식제분에 비해 습식제분에서 손상도가 더 크다고 보고하였고, 일반미의 경우 메성 품종이 찰성 품종에 비해 손상전분 함량이 높게 나타난다고 보고하였다. 또한, Tipples(35)은 손상전분은 밀 가루의 수분 흡수 능력의 증가를 초래한다고 보고하였다.

\section{쌀가루의 입도 및 색도 분석}

초다수성 쌀품종을 이용하여 건식 기류 분쇄에 의해 제 조된 쌀가루의 입도 및 색도를 분석하였다(Table 3 4). 한아 름 및 다산 2 호 쌀가루의 평균 입도는 각각 50.05 및 49.50 $\mu \mathrm{m}$ 를 나타냈으며 대조구의 경우 $48.54 \mu \mathrm{m}$ 의 평균 입도를 나타내었다. 색도 분석 결과 명도는 대조구가 92.63을 나타 낸 반면 한아름 및 다산 2호 쌀가루의 명도는 각각 93.72 및 93.51을 나타내어 대조구보다 쌀가루가 높은 명도를 나 타내는 것으로 확인하였다. Lee(32)는 시중 유통되는 쌀가 루의 입도의 경우 32.11 305.67 $\mu \mathrm{m}$ 를 나타낸다고 보고하였 다. Jung와 Choi(36)는 도정도에 의한 쌀가루의 색도를 분석 한 결과 명도의 경우 백미 쌀가루가 93.72로 가장 높았고, 현미 쌀가루는 88.08로 가장 낮았다고 보고 하였다. Lee(37) 는 국내 쌀 품종 쌀가루의 입도가 작을수록 수분흡수지수 (WAI)가 높은 경향을 나타낸다고 보고하였는데 이는 본 연구결과와 유사한 경향을 나타냈다.

Table 3. Particle sizes of the super-yield Korean rice varieties

\begin{tabular}{cccc}
\hline Samples & Mean $(\mu \mathrm{m})$ & Median $(\mu \mathrm{m})$ & $\begin{array}{c}\text { Mean/Median } \\
\text { ratio }\end{array}$ \\
\hline Control & $48.54 \pm 0.46^{\mathrm{b} 1)}$ & $31.53 \pm 0.39^{\mathrm{b}}$ & $1.49^{\mathrm{a}}$ \\
Hanareum & $50.05 \pm 0.15^{\mathrm{a}}$ & $38.28 \pm 0.20^{\mathrm{a}}$ & $1.31^{\mathrm{b}}$ \\
Dasan 2 & $49.50 \pm 1.13^{\mathrm{ab}}$ & $38.94 \pm 1.67^{\mathrm{a}}$ & $1.27^{\mathrm{c}}$ \\
\hline${ }^{1)}$ Different letters within the same column differ significantly $(\mathrm{p}<0.05)$.
\end{tabular}

Table 4. Hunter color values of the super-yield Korean rice varieties

\begin{tabular}{cccc}
\hline Samples & $\mathrm{L}^{*}$ & $\mathrm{a}^{*}$ & $\mathrm{~b}^{*}$ \\
\hline Control & $92.63 \pm 0.07^{\mathrm{b} 1)}$ & $-1.24 \pm 0.01^{\mathrm{b}}$ & $8.61 \pm 0.15^{\mathrm{a}}$ \\
Hanareum & $93.72 \pm 0.19^{\mathrm{a}}$ & $-0.64 \pm 0.01^{\mathrm{a}}$ & $3.67 \pm 0.02^{\mathrm{b}}$ \\
Dasan 2 & $93.51 \pm 0.14^{\mathrm{a}}$ & $-0.63 \pm 0.01^{\mathrm{a}}$ & $3.36 \pm 0.02^{\mathrm{c}}$ \\
\hline
\end{tabular}

${ }^{1)}$ Different letters within the same column differ significantly $(\mathrm{p}<0.05)$. 
쌀냉동생지의 해동 시간에 따른 품질 특성 변화

쿠키용 쌀냉동반죽의 높이 및 직경이 $5 \times 50 \mathrm{~mm}$ 가 되도록 모양을 성형한 후 $-20^{\circ} \mathrm{C}$ 냉동고에서 24 시간 냉동하였다. 쿠키용 쌀냉동반죽은 냉동고에서 꺼내어 각각 해동시간 $(0$, 10,30 및 50 분)에 따라 해동한 후 $180^{\circ} \mathrm{C}$ 오븐에서 20 분간 구운 후 상온에서 30 분 동안 방랭하여 쿠키의 색도, 직경, 높이 및 경도를 분석하였으며 그 결과는 Table 5,6 과 같다. 한아름 및 다산 2호를 이용하여 제조된 쌀냉동반죽의 경우 해동시간 없이 바로 구운 쿠키의 명도는 84.98 및 84.63을 나타낸 반면 50 분 동안의 해동을 거쳐 제조된 쿠키의 명도 는 82.81 및 83.89 로 나타나 유의적으로 감소하는 것으로 확인되었다(Table 5). 한아름 쌀가루로 제조된 냉동반죽은 해동시간 30 및 50 분 경과하여 제조된 쿠키의 적색도는 - 1.07 및 -1.82 로 대조구인 - 2.07과 비교시 높게 나타났 으며 다산 2 호를 이용한 냉동반죽 이용 쿠키의 적색도의 경우도 유사한 경향을 나타냈다. 또한, 초다수성 쌀가루로 제조된 냉동반죽이용 쿠키의 황색도의 경우도 적색도와 유사하게 높아지는 경향을 나타내었다. 또한, 대조구 및 쌀가루로 제조된 냉동반죽을 이용한 쿠키의 명도와 황색도 의 경우 박력분 및 쌀가루의 색도와 유사한 경향을 나타났 으며, 쌀냉동반죽을 이용하여 제조된 쿠키의 명도는 해동 시간이 증가할수록 감소하는 경향을 나타냈다. 그러나 본 연구결과 쌀가루로 제조된 냉동반죽을 이용한 쿠키의 적색 도는 해동시간에 따라 증가하는 경향을 나타내었는데, 이 는 쿠키 제조시 사용 원료 및 부재료 등의 가열처리에 의한 갈색화 반응 등에 의해 기인한 것이라고 사료된다. Laguna 등(38)은 당의 메일라드 반응 및 카라멜 반응은 굽는 동안 갈색 물질의 생산에 기여한다고 보고하였고, 이러한 갈변 반응은 수분 활성도, 온도, 당, 아미노산의 비율, $\mathrm{pH}$ 등과 같은 요인에 의해 영향을 받는다고 보고하였다 $(39,40)$.

쿠키용 쌀냉동반죽을 이용하여 제조한 쿠키의 직경, 높 이 및 경도를 분석하였다(Table 6). 냉동반죽 이용 쿠키의 품질 특성은 대조구를 이용한 쿠키의 직경 및 높이가 가장 높게 나타났으며 경도는 가장 낮게 나타났다. 쿠키용 쌀냉 동반죽을 이용하여 제조한 쿠키의 직경은 해동 시간에 따른 유의적인 차이는 나타나지 않았으나 쿠키 두께의 경우 한아 름 쌀가루를 이용한 냉동반죽은 해동 후 바로 구웠을 때 두께가 가장 높았고, 다산 2호 쌀가루를 이용한 냉동반죽은 30 분간 해동 후 구운 쿠키의 두께가 $8.9 \mathrm{~mm}$ 로 가장 높은 것으로 확인되었다. 대조구의 경우 30 분 동안 해동하여 구 운 쿠키의 직경이 가장 넓게 나타났으며 쿠키 두께의 경우 해동시간에 따른 유의적인 차이를 보이지 않았다. 쌀냉동 반죽을 이용하여 제조한 쿠키의 경도를 분석한 결과 쌀가루 중 다산 2 호를 이용하여 제조한 쌀냉동반죽은 해동 후 바로 구운 쿠키의 경도가 $980.78 \mathrm{~g}$ 로 가장 낮게 나타났으며, 쌀냉 동생지를 이용한 쿠키의 경도는 해동시간이 증가함에 따라 증가하는 경향을 나타냈다. 본 연구 결과 대조구로 이용된
박력분과 쌀가루로 제조된 냉동반죽 이용 쿠키의 품질은 서로 차이를 나타내는데, 이는 사용 원료의 이화학적인 특 성에 기인하여 냉동된 반죽의 품질에 영향을 미치는 것으로 사료된다. 쌀가루를 이용한 가공식품의 품질은 쌀가루 제 분시의 특성변화와 주성분인 전분 특성에 의해 결정되는 것으로 보고되고 있다(41). Lee(32)는 손상전분의 함량이 높은 시료의 경우 수분 결합력이 높고, 입도 크기가 작은 쌀가루의 시료는 최종 점도가 높은 경향을 나타낸다고 보고

Table 5. Changes in the color values of the cookies made with frozen rice dough according to the thawing time

\begin{tabular}{ccccc}
\hline \multirow{2}{*}{ Samples } & \multirow{2}{*}{$\begin{array}{c}\text { Thawing time } \\
(\mathrm{min})\end{array}$} & \multicolumn{3}{c}{ Color value } \\
\cline { 3 - 5 } & 0 & $81.46 \pm 1.59^{1)}$ & $-2.07 \pm 0.06^{\mathrm{ab}}$ & $32.22 \pm 0.33$ \\
\hline Control & 10 & $81.10 \pm 0.52$ & $-2.28 \pm 0.37^{\mathrm{b}}$ & $32.86 \pm 0.52$ \\
& 30 & $80.36 \pm 0.23$ & $-1.61 \pm 0.34^{\mathrm{a}}$ & $32.94 \pm 1.16$ \\
& 50 & $78.10 \pm 5.62$ & $-2.30 \pm 0.38^{\mathrm{b}}$ & $31.20 \pm 2.36$ \\
& 0 & $84.98 \pm 0.47^{\mathrm{a}}$ & $-2.50 \pm 0.01^{\mathrm{c}}$ & $22.51 \pm 0.79^{\mathrm{c}}$ \\
\hline Hanareum & 0 & $84.79 \pm 0.38^{\mathrm{a}}$ & $-2.71 \pm 0.04^{\mathrm{c}}$ & $21.90 \pm 0.49^{\mathrm{c}}$ \\
& 10 & $82.26 \pm 0.64^{\mathrm{b}}$ & $-1.07 \pm 0.19^{\mathrm{a}}$ & $28.31 \pm 0.64^{\mathrm{a}}$ \\
& 30 & $82.81 \pm 0.65^{\mathrm{b}}$ & $-1.82 \pm 0.22^{\mathrm{b}}$ & $25.84 \pm 0.85^{\mathrm{b}}$ \\
\hline \multirow{2}{*}{ Dasan 2 } & 50 & $84.63 \pm 0.64$ & $-2.76 \pm 0.13^{\mathrm{b}}$ & $25.50 \pm 0.16^{\mathrm{b}}$ \\
& 0 & $84.01 \pm 0.23$ & $-2.81 \pm 0.09^{\mathrm{b}}$ & $25.38 \pm 0.60^{\mathrm{b}}$ \\
& 10 & $84.42 \pm 0.96$ & $-2.25 \pm 0.38^{\mathrm{a}}$ & $26.27 \pm 0.74^{\mathrm{b}}$ \\
& 30 & $83.89 \pm 0.69$ & $-2.25 \pm 0.24^{\mathrm{a}}$ & $28.44 \pm 0.47^{\mathrm{a}}$ \\
\hline
\end{tabular}

${ }^{1)}$ Different letters within the same column differ significantly $(\mathrm{p}<0.05)$.

Table 6. Changes in the diameter, thickness, and hardness of the cookies made with frozen rice dough according to the thawing time

\begin{tabular}{ccccc}
\hline Samples & $\begin{array}{c}\text { Thawing } \\
\text { time } \\
(\mathrm{min})\end{array}$ & $\begin{array}{c}\text { Diameter } \\
(\mathrm{mm})\end{array}$ & $\begin{array}{c}\text { Thickness } \\
(\mathrm{mm})\end{array}$ & $\begin{array}{c}\text { Hardness } \\
(\mathrm{g})\end{array}$ \\
\hline Control & 0 & $55 \pm 0.6^{\mathrm{cl}}$ & $10.0 \pm 0.2$ & $585.01 \pm 15.66^{\mathrm{b}}$ \\
& 10 & $58 \pm 0.6^{\mathrm{a}}$ & $9.7 \pm 0.3$ & $773.75 \pm 80.96^{\mathrm{a}}$ \\
& 30 & $57 \pm 1.0^{\mathrm{ab}}$ & $9.7 \pm 0.4$ & $620.49 \pm 101.74^{\mathrm{b}}$ \\
& 50 & $56 \pm 1.0^{\mathrm{bc}}$ & $9.7 \pm 0.2$ & $537.30 \pm 78.24^{\mathrm{b}}$ \\
\hline Hanareum & 0 & $53 \pm 0.1$ & $8.8 \pm 0.2^{\mathrm{a}}$ & $1,054.84 \pm 63.81^{\mathrm{c}}$ \\
& 10 & $53 \pm 0.6$ & $8.2 \pm 0.4^{\mathrm{b}}$ & $1,090.82 \pm 124.68^{\mathrm{c}}$ \\
& 30 & $51 \pm 1.5$ & $8.7 \pm 0.3^{\mathrm{ab}^{\mathrm{b}}}$ & $1,905.47 \pm 448.09^{\mathrm{a}}$ \\
& 50 & $52 \pm 1.0$ & $8.4 \pm 0.1^{\mathrm{ab}}$ & $1,852.13 \pm 495.49^{\mathrm{b}}$ \\
\hline Dasan 2 & 0 & $52 \pm 1.5$ & $8.6 \pm 0.1^{\mathrm{b}}$ & $980.78 \pm 35.34^{\mathrm{c}}$ \\
& 10 & $53 \pm 1.0$ & $8.3 \pm 0.2^{\mathrm{c}}$ & $2,039.22 \pm 63.15^{\mathrm{b}}$ \\
& 30 & $52 \pm 1.0$ & $8.9 \pm 0.1^{\mathrm{a}}$ & $2,833.65 \pm 721.10^{\mathrm{a}}$ \\
& 50 & $52 \pm 1.0$ & $8.6 \pm 0.1^{\mathrm{b}}$ & $2,019.54 \pm 113.64^{\mathrm{b}}$ \\
\hline
\end{tabular}

${ }^{1}$ Different letters within the same column differ significantly $(p<0.05)$. 
하였다. 또한 아밀로오즈 함량이 높은 일반 메성 품종의 경우 수분함량 및 입도가 작은 시료가 최고점도를 나타내었 으며, 최종점도도 높게 나타나는 경향을 나타냈다(37). 또 한 밀가루의 단백질 함량도 냉동생지 제품에 영향을 미치는 데, 단백질 함량이 높은 밀가루로 제조된 데니쉬 페이스트 리 냉동생지 이용 제품의 부피 및 경도는 가장 높게 나타났 다고 보고하였다(21). 이는 본 연구에서 단백질 함량이 높고 아밀로오즈 함량이 낮은 쌀가루로 제조된 쌀냉동생지를 바로 구웠을 경우 쿠키의 경도가 높게 나타난 결과와 유사 하였다. 본 연구 결과 국내 초다수성 쌀가루를 이용하여 제조한 쿠키용 냉동반죽을 이용한 쿠키의 품질 분석 결과 명도의 경우 대조구보다 쌀가루 이용한 냉동생지 가공제품 의 명도가 높게 나타나는 특성을 보였으며, 쌀가루 중 다산 2 호를 이용하여 제조된 냉동반죽을 해동 후 바로 구운 쿠키 는 경도가 가장 낮게 나타났으나, 초다수성 쌀가루를 이용 하여 제조한 쿠키의 경도는 해동시간이 증가함에 따라 경도 는 증가하는 것으로 확인하였다.

\section{요 약}

초다수성 쌀품종인 한아름 및 다산 2 호 쌀가루의 이화학 적 특성을 분석하고, 이를 이용하여 제조한 쿠키용 쌀냉동 반죽의 품질 특성에 대해 조사하였다. 초다수성 쌀가루의 이화학적 특성은 수분 함량, 회분 함량, 단백질 함량, 아밀로 오즈 함량, 손상전분, 수분 결합력, 입도 및 색도에 대해 분석하였다. 한아름 및 다산 2 호 쌀가루, 대조구의 수분함 량 및 회분 함량은 각각 $7.70,7.28,13.14 \%$ 및 $0.39,0.35$, $0.39 \%$ 로 나타났다. 또한 단백질 함량의 경우 대조구가 $8.68 \%$ 로 한아름 및 다산 2호 쌀가루의 6.62 및 $6.05 \%$ 보다 높게 나타났다. 한아름 및 다산 2호 쌀가루의 아밀로오즈 함량은 각각 19.05 및 $23.04 \%$ 를 나타냈다. 손상전분의 경우 한아름 및 다산 2 호 쌀가루는 각각 13.73 및 $14.09 \%$ 의 전분 손상도를 나타냈으며 대조구의 경우 $4.45 \%$ 의 전분 손상도 를 나타내어 쌀가루의 전분 손상도가 높음을 확인하였다. 수분 결합력의 경우 대조구의 경우 $177.69 \%$ 의 수분 결합력 을 보인 반면 한아름 및 다산 2 호 쌀가루의 수분 결합력은 270.50 및 281.17\%로 높은 수분 결합력을 나타내는 것으로 확인하였다. 또한, 한아름 및 다산 2 호 쌀가루의 평균 입도 는 각각 50.05 및 $49.50 \mu \mathrm{m}$ 를 나타냈으며 대조구의 경우 $48.54 \mu \mathrm{m}$ 의 평균 입도를 나타냈다. 시료의 색도 분석의 경우 대조구 명도는 92.63을 나타낸 반면 한아름 및 다산2 호 쌀가루는 93.72 및 93.51 을 나타내어 대조구보다 높은 명도를 나타내는 것으로 확인하였다. 초다수성 쌀가루를 이용한 쿠키용 쌀냉동반죽의 해동시간에 따른 품질 특성을 분석하였다. 쌀냉동반죽 이용 쿠키의 명도는 해동 시간이 증가할수록 명도가 감소하는 경향을 나타냈다. 쿠키용 쌀
냉동반죽을 이용하여 제조한 쿠키의 직경은 해동 시간에 따른 유의적인 차이는 나타내지 않았으나 쿠키 두께의 경우 다산 2 호 쌀가루 이용한 냉동반죽을 30 분간 해동 후 구운 쿠키의 두께가 가장 높은 것으로 확인되었다. 쌀냉동반죽 을 이용하여 제조한 쿠키의 경도를 분석한 결과 초다수성 쌀가루 중 다산 2 호 쌀가루를 이용하여 제조한 냉동반죽을 해동 후 바로 구운 쿠키의 경도가 $980.78 \mathrm{~g}$ 로 가장 낮게 나타났다.

\section{감사의 글}

본 논문은 농촌진흥청 연구사업(과제번호 : PJ00780803 및 PJ01027104)의 지원에 의해 이루어진 연구결과의 일부 이며 이에 감사드립니다.

\section{References}

1. Choi DR, Lee JH, Yoon YC, Lee SK (2005) Effect of vital wheat gluten on the quality characteristics of the dough frozen after 1st fermentation. Korean J Food Sci Technol, 37, 55-60

2. Korean Bakers Association (1995) What is frozen dough 6: The monthly bakery, p 58-60

3. Davis EW (1981) Shelf-life studies on frozen doughs. Bakers Digest, 55, 12-17

4. Tanaka Y, Nakae T (1982) Theory and practice of frozen dough. Food Research Center, Tokyo Japan, p 13-17

5. Korean Bakers Association (1996) The present and future of frozen dough technology 5: The monthly bakery, $\mathrm{p}$ 96-98

6. El-Hady EAA, El-Samahy SK, Brummer JM (1999) Effect of oxidants, sodium-stearoyl-2-lactylate and their mixtures on rheological and baking properties of non prefermented frozen doughs. Lebensm Wiss Technol, 32, 445-454

7. Xu A, Chung OK, Ponte JG (1992) Bread crumb amylograph studies (I) : effect of shortening, flou lipid and surfactant. Cereal Chem, 69, 495-501

8. Dubois DK, Blochcolsdy D (1986) Frozen bread dough : effect of additives. Am Inst Baking Tech Bull, 8, 1-7

9. Lee JM, Lee MK, Lee SK, Cho NJ, Kim SM (2001) Effect of gums added in making frozen dough on the characteristics of bread-making. Korean J Food Sci Technol, 33, 190-194

10. Selomulyo VO, Zhou W (2007) Frozen bread dough : 
effects of freezing storage and dough improvers. J Cereal Sci, 45, 1-17

11. Rouile J, Le Bail A, Coucoux P (2000) Influence of formulation and mixing conditions on bread making qualities of french frozen dough. J Food Eng, 43, 197-203

12. Inoue Y, Bushuk W (1991) Studies on frozen doughs. I . Effects of frozen storage and freeze thaw cycles on baking quality and rheological properties. Cereal Chem, 68, 627-631

13. Le Bail A, Havet M, Pasco M (1998) Influence of the freezing rate and of storage duration on the gassing power of frozen bread dough. International Congress of Refrigeration, Nantes, France, p 16-18

14. Lu W, Grant LA (1999) Effects of prolonged storage at freezing temperatures on starch and baking quality of frozen doughs. Cereal Chem, 76, 656-662

15. Neyreneuf O, Delpuech B (1993) Freezing experiments on yeasted dough slab. Effects of crygenic temperatures on the baking performance. Cereal Chem, 70, 109-111

16. Lucas T, Grenier A, Quellec S, Le Bail A, Davenel A (2005) MRI quantification of ice gradients in dough during freezing or thawing process. J Food Eng, 71, 98-108

17. Hahn YS (2004) Study on the freezing conditions for the frozen-dough preparation of bread. J East Asian Soc Dietary Life, 14, 443-448

18. Lee J, Lee MK, Lee SK, Cho NJ, Cha WJ, Park JK (2000) Effect of gums on the charactistics of the dough in making frozen dough. Korean J Food Sci Technol, 32, 604-609

19. Lee JH, Choi DR, Lee SK, Lee JK (2004) Effect of emulsifiers on properties of the bread made by the dough frozen after first fermentation. J Korean Soc Appl Biol Chem, 47, 107-112

20. Kim SY, Han JH, Song Y, Lee SK (2003) The effect of the ash content in flour on the rheological properties of frozen dough. J Korean Soc Agric Chem Biotech, 46, 39-45

21. Yun MS (2004) The effect of flours protein contents to the properties of the danish pastry made with frozen dough. Korean J Food Nutr, 17, 322-327

22. Kim YK, Chun A (2010) Status and prospects of rice varieties for processing. Food Preser Processing Ind, 9, 3-12

23. Lee MK, Shin M (2006) Characteristics of rice flours prepared by moisture heat treatment. Korean J Food Cookery Sci, 22, 147-157
24. Kim EM (2010) The properties of rice flours prepared by dry and wet milling method. Korean J Food Cookery Sci, 26, 727-736

25. Kum JS (2010) Expansion of rice consumption by rice processing technology through innovation. Food Preserv Processing Ind, 9, 49-59

26. Kim YK (2010) Status and prospects of rice varieties development. Food Preserv Processing Ind, 9, 75-82

27. AOAC (1984) Official method of analysis of AOAC Intl. 14th ed. Method 930.15. Association of Official Analytical Chemists, Arlington, VA, USA

28. Juliano BO (1971) Simplified assay for milled-rice amylose. Cereal Science Today, 16, 334-340, 360

29. Gibson TS, Solah VA, McCleary BV (1997) Procedure to measure amylose in cereal starches and flours with concanavalian. A J Cereal Sci, 25, 111-119

30. Medcalf DF, Gilles KA (1965) Wheat starches. I . Comparison of physicochemical properties. Cereal Chem, 42, 558-568

31. Kim WS, Shin M (2007) The properties of rice flours prepared by dry- and wet-milling of soaked glutinous and normal grains. Korean J Food Cookery Sci, 23, 98-918

32. Lee NY (2012) Starch and pasting charactristics of various rice flours collected from markets. Korean J Food Preserv, 19, 257-262

33. Lee MH, Lee YT (2006) Bread-making properties of rice flours produced by dry, wet and semi-wet milling. J Korean Soc Food Sci Nutr, 35, 886-890

34. Jun HI, Yang EJ, Kim YS, Song GS (2008) Effect of dry and wet millings on physicochemical properties of black rice flours. J Korean Soc Food Sci Nutr, 37, 900-907

35. Tipples KH (1969) The relation of starch damage to the baking performance of flour. Baker's Digest, 43, 28

36. Jung HN, Choi OJ (2014) Different milling degree of rice cultivar "Deuraechan". Korean J Food Cook Sci, 30, 139-145

37. Lee NY (2013) Starch and quality characteristic of Korean rice cultivar with waxy and non waxy type. Korean J Crop Sci, 58, 226-231

38. Laguna L, Salvador A, Sanz T, Fiszman SM (2011) Performance of a resistant starch rich ingredient in the baking and eating quality of short-dough biscuits. LWT-Food Sci Technol, 44, 737-746

39. Sharma P, Gujral HS (2013) Extrusion of hulled barley affecting $\beta$-glucan and properties of extrudates. Food 
Bioprocess Technol, 6, 1374-1389

40. Stojceska V, Ainsworth P, Plunkett A, Ibanoglu S (2009) The effect of extrusion cooking using different water feed rates on the quality of ready-to-eat snacks made from food by-products. Food Chem, 114, 226-232

41. Juliano BO (1985) Criteria and tests for rice grain qualities. In: Rice Chemistry. ACC. St. Paul, MN, USA, p 443-524 